Journal of Money and Economy

Vol. 16, No. 3, Summer 2021

pp. 305-322

DOI: $10.29252 /$ jme.16.3.305

Original Research Article

\title{
Investigating the Relationship between Money Growth and Inflation in Turkey: A Nonlinear Causality Approach
}

\author{
Ebrahim Eltejaei $^{*} \quad$ Jalal Montazeri Shoorekchali $^{\dagger}$
}

Received: 28 Jun $2021 \quad$ Approved: 13 Feb 2022

Theories on the relationship between money and inflation had largely been shaped around the positive relationship and money causality for inflation before the PostKeynesians. Since the 1980 s, this idea emerged that there might be no correlation between money growth and inflation. In the case of existence, the causality is reversed, so money is endogenous somehow. However, practically there is a suspicion that the causality between money growth and inflation is not fixed and linear. According to the experience of Turkey in the last seven decades, which has experienced fluctuated inflation rates, it is supposed that the causal relationship between Broad Money Growth (BMG) and inflation is not constant. This paper examines this idea over 1961-2019 using a Markov Switching Vector Autoregressive model (MS-VAR), which allows for regime shifts. Findings show that the causal relationship between BMG and inflation has not been constant, and different regimes have generated different causality orientations. There was a one-way causality from inflation to BMG during 1971-2001 that inflation rates were high. Whereas, during 1961-70 and 2002-19, when the Turkish economy experienced milder inflation rates, there was a one-way causal relationship from BMG to inflation.

Keywords: Broad Money Growth, Inflation, Markov Switching Granger Causality, Reverse Causality, Turkish Economy

JEL Classification: E31, E51

\section{Introduction}

One of the most important and controversial issues in monetary economics is the causality between money and inflation. Knowing this causality is very important in policies for controlling inflation. According to the classical

\footnotetext{
* Department of Economics, Institute for Humanities and Cultural Studies, Tehran, Iran; e. eltejaei@ihcs.ac.ir (Corresponding Author)

$\dagger$ Department of Economics, Institute for Humanities and Cultural Studies, Tehran, Iran; j.montazeri@ihcs.ac.ir
} 
approach, from the quantity theory to monetarism and modern classical school, a relationship between money and inflation is recognized, and controlling inflation depends on controlling the growth of money. Especially, according to Monetarism, inflation is solely due to the growth of the money supply.

With the advent of the post-Keynesian approach and the unsuccessful experience of achieving money growth and inflation targets in the United States during the 1980s, this idea emerged that there is no correlation between money growth and inflation (Holt and Pressman, 2001). Hence, in the late 1980s, consensus on targeting monetary aggregates and inflation largely faded. From the 1990s onwards, another monetary policy to control inflation was replaced by controlling economic growth and unemployment.

Based on theoretical literature, two streams of causality between money and inflation are visible. Depending on economic situations, stability or instability, elasticity or inelasticity of price expectations, and economic booms or recessions, either of these two streams of causality can be considered relevant. Maybe both sides are acceptable, but depending on the economic situation, the strengths and weaknesses of each one are different.

Nevertheless, there are only a few empirical studies like Amisano and Colavecchio (2013), Amisano and Fagan (2013), Cooray and Khraief (2019), and Eltejaei (2020), that, unlike the conventional literature, have supposed a nonlinear relationship between money and inflation. Supposing linearity in most studies has reduced their accuracy.

Therefore, in order to understand the dynamics of the relationship between money growth and inflation, this paper tries to examine a nonlinear relationship for the Turkish economy using an empirical test. The Turkish economy has experienced different inflation and money growth periods from 1961-2019. Inflation has been varied from 1 percent to the high levels of above 100 percent, and money growth has fluctuated between 9 to 144 percent. These experiences give us a good sample to test this causality. The hypothesis is that for the years of high inflation rates, the reverse causality (i.e., the causality from inflation to money growth) has played a significant role in destabilizing dynamics of the broad money growth. In other words, the causal relationship between money growth and inflation has not been the same in all years, and there has been a nonlinear relationship between them.

The remainder of this paper is organized as follows. Section 2 provides a brief literature review on the causality between money and inflation. In Section 3, methodology and model specifications are presented. Section 4 
provides data and empirical results of the model. Finally, Section 5 concludes the paper.

\section{Theoretical Literature Review}

The history of cognition of the relationship between money and inflation can be traced back to David Hume. Hume (1752a) described two channels for the effects of money supply on the economy. Based on the first channel, later was known as the direct channel by Fisher (1911) and the Monetarists in the 1970s, if the increase in money supply initially ended up in the hands of people who usually spent their extra funds to buy commodities, it would not affect lowering interest rates and not increasing investment and output. In this case, the only effect of the increase in money supply will be the increase in prices. The second channel, known as the indirect transmission channel, operates mainly if the initial increase in the money supply ends up in lump sums in the hands of lenders, whose modern counterpart is primarily financial institutions. The relative strength of each channel depends on the structure of the economy and the diffusion of the new money balances (Handa, 2009). So, the direct transmission channel is more important in poor economies, and therefore money growth has a greater impact on price levels.

Hume (1752b) explained the initial version of the quantity theory, which states that increasing the supply of money leads to a proportional increase in prices. But his analysis in the context of the gold standard system (corresponds to the fixed exchange rate system) indicates that trade activities will change the aggregate money, since, in the gold standard system, monetary aggregate is determined by the balance of payments, which in turn depends on relative prices and the relative competitiveness of exports. Therefore, it can be said that from Hume's point of view, a two-way causality can be seen between monetary aggregates and price levels.

Fisher (1911) mainly emphasized the direct channel between the two mentioned channels. This emphasis on the direct channel, by Fisher and Hume, and later by monetarists on the direct channel, indicates the impact of money on inflation. Fisher (1911) also explicitly emphasizes the proportional impact of money supply on price by proposing quantity theory.

Cambridge's cash balance approach as an alternative to the quantity theory examined the determination of prices from the perspective of money supply and demand. According to Pigou (1917), the price elasticity relative to the money supply equals one in equilibrium. In adaptive static equilibria, the price level will change proportionally with the money supply. 
According to Wicksell (1907), the accumulation of price increases is usually the result of an exogenous rise of the difference between marginal productivity of capital and the market interest rates, which firstly leads to an increase in money supply and credit and then to a rise in prices.

Based on his empirical studies, Friedman claimed, "Inflation is always and everywhere a monetary phenomenon." This famous claim was one of his and the monetarism school's most important contributions to monetary economics (Friedman and Schwartz, 1963; Friedman 1958). Friedman's contributions also showed that changes in the money supply could strongly affect both real and nominal output. In brief, the 1970s monetarism argued that money supply is controlled by the central bank exogenously, and inflation is solely due to the growth of money supply, and money is all that matters.

Based on Keynes's general theory, the supply of money is exogenous. Since the demand for money is a negative function of interest rates, any endogenous "monetary capacity" arises exclusively from money demand. In neo-Keynesian models, outside money is separated from inside money. Outside money refers to central bank debts, and inside money refers to bank deposits. Outside money is exogenous and under the central bank's control, while inside money is endogenous and is created by the banking system through the mechanism of the monetary base multiplier. Thus, the money supply is endogenous, and the exogenous element will be hidden in the background. Inside money supply depends on the volume of the monetary base and its multiplier. The elasticity of the inside money supply depends on the sensitivity of the monetary base multiplier to the interest rate. The size of the monetary base multiplier also inversely depends on the volume of reserve requirements.

Based on monetarists and the rational expectations theory, with the acceptance of money neutrality, this idea was widely accepted that monetary policy should target monetary aggregates to control inflation. With the advent of post-Keynesian views and unsuccessful experience of achieving money growth and inflation targets in the United States during the 1980s, this idea emerged that there is no correlation between money growth and inflation (Holt and Pressman, 2001). Thus, in the late 1980s, consensus on targeting monetary aggregates was faded, and since the early 1990s, another monetary policy to control inflation was emerged by targeting economic growth and unemployment. Therefore, to some extent, the post-Keynesians rejected the causal relationship of money supply and inflation.

Some experts of the modern monetary theory, such as Tymoigne and Wray (2013), argued that inflation is a real, not a financial constraint. According to 
them, modern monetary theory rejects the quantity theory explanation for inflation. Inflation occurs when government expenditures and taxation are disproportionate, not when the ratio of money to GDP is high.

In brief, based on the theoretical literature, it can be said that although the positive correlation between monetary aggregates and the level of prices or inflation is accepted in the orthodox economic approach, the degree of this correlation and the causality orientation is not as straightforward as that relationship. Hence, examining this relationship and causality orientation empirically will be illustrative.

\section{Empirical Studies}

Empirically, many studies have investigated the causal relationship between money supply growth and inflation, but only a few studies investigate the nonlinearity of this relationship. The first group of studies has examined the relationship based on a linear approach. Generally, they have reported conflicting results with respect to the sample. Some of them, for instance, Kesavarajah and Amirthalingam (2012) for Sri Lanka: 1978-2010; Kiganda (2014) for Kenya: 1984-2012; Korkmaz (2018) for selected Mediterranean countries: 2008-2014 and Sasongko \& Huruta (2018) for Indonesia: 2007:12017:7 showed that there was a one-way causal relationship from money growth to inflation. Also, Benderly and Zwick (1985) for the U.S., Fatma Turan (2014) for Turkey, Jones and Uri (1986) for the U.S., and Jones and Khilji (1988) for Pakistan found that money growth has affected inflation.

Some others, like Indalmanie (2011) for Jamaica: 1961-2006 and Göçmen (2016) for Turkey: 1970-2006, suggested a reverse one-way causality relationship. On the other hand, Zulkhibri (2007) for Malaysia: 1979-2000; Atrkar Roshan (2014) for Iran: 1988-2010; Denbel et al. (2016) for Ethiopia: 1970-2010; Aghevli and Khan (1978) for Brazil, Colombia, Dominican Republic, and Thailand: 1964-1994, and Sultana et al. (2019) for Bangladesh: 2010:05-2017:12 found a two-way causality between the amount of money and inflation. In contrast, Turnovsky and Wohar (1984) for the U.S., 19291978 found no evidence of the relationship between money and inflation.

The second group of studies has examined the nonlinear relationship between money and inflation. For example, Amisano and Colavecchio (2013) studied the relationship between money growth and inflation in a Bayesian MS framework for four countries, including the U.S., the U.K., the Euro area, and Japan, during 1960-2012. They found a relatively weak relationship between money and inflation while featuring low and stable inflation. Amisano and Fagan (2013) developed an M.S. model with time-varying 
transition probabilities for the euro area, Germany, the U.S., the U.K., and Canada for 1960-2009. They argued that a smoothed measure of broad money growth had important properties of a leading indicator of switching between different inflation regimes. Thus, money growth is an important early warning indicator of risks to price stability. For the U.S., the U.K., and Japan, Cooray, and Khraief (2019) applied Nonlinear Auto-Regressive Distributed Lag (NARDL) model and found that inflation responded asymmetrically to monetary shocks in the long-run for the period 1950:1- 2014:4. Eltejaei (2020), using an MS-VAR model, showed that three different regimes could be identified for money growth and inflation in Iran during the 1961-2017 period. Mehrara and Behzadi Soufiani (2015), using a threshold model, examined the nonlinear effects of fiscal and monetary policies on inflation during 1990:3 to 2013:1in Iran and recognized two different regimes. Based on their results, it seems that liquidity growth can be considered the most important factor for regime change in the relationship between inflation and fiscal and monetary policies in the economy.

Based on empirical studies, two points are worth mentioning: First, most of these studies have found different results depending on their sample. Therefore, the causal relationship between money growth and inflation in each country is needed to be examined separately. Second, we should consider Hamilton's (1994) view that the behavior of many time series would vary in different periods due to different conditions. Hamilton (1994) emphasized that factors such as economic crises, changes in government policies, wars, and financial panic could create different regimes or situations for variables. Therefore, studying the behavior of variables in such a context in the form of a linear approach may not be error-free. Also, as said before, the Turkish economy has experienced diversified periods of inflation and money growth during 1961-2019. More explanations on Inflation and money growth trends in Turkey are provided in the next sections. Despite these diversified situations, all studies on Turkey have seen a linear relationship and have ignored different regimes. Hence, this study investigates the nonlinear causality between money growth and inflation.

\section{Methodology and Model Specification}

As said before, based on the theoretical literature, the positive correlation between monetary aggregates and the level of prices or inflation is accepted in the orthodox economic approach, but the degree of this correlation and the causality orientation is not as straightforward as that relationship. Also, depending on their sample, most empirical studies have shown different 
results on the causal relationship between money growth and inflation. Therefore, the defensible idea is that the causal relationship between inflation and money growth may not be fixed depending on the sample and time requirements.

As Hamilton (1994) pointed out, the different behaviors of many time series in different periods and conditions due to various factors could create different regimes or situations for the variables. Therefore, studying the behavior of variables in such a context in the form of a linear approach might not be error-free (Deschamps, 2008), and we have to hire models to consider nonlinearity. Hence, we use an MS-VAR model to examine the nonlinear causal relationship between money growth and inflation.

The MS-VAR Model is a generalized model of a basic VAR model of order P. This model was introduced by Quandt (1972) and Quandt and Goldfeld (1973) and developed by Hamilton (1989) to extract business cycles. After Hamilton's study, Markov switching models have been widely used to analyze various economic phenomena. Various applications and methods of estimating Markov switching models are well mentioned in Krolzig's (1997) and Kim and Nelson's (1999) studies.

The main idea in the MS-VAR model is that if the time series are subject to shifts in the regime, the stable VAR model with its time-invariant parameters might be inappropriate. Then, the M.S.-VAR model might be considered a general regime-switching framework. The general idea behind this class of models is that the parameters of the underlying data generating process of the observed time series vectors depend on the unobservable regime variables, which represents the probability of being in a different state. Regime-dependent parameters in this model could be the intercepts (I), the autoregressive coefficients $(\mathrm{A})$, the variance $(\mathrm{H})$, or their combinations. For example, an MSI model denotes an M.S. model with a regime-dependent intercept. An MSIA model denotes an M.S. model where the intercept and the autoregressive coefficients are regime-dependent. MSIAH shows a model that intercepts, autoregressive parameters, and variances are regime-dependent (Fallahi, 2011: 4168). Different models of MS-VAR can be considered, as are shown in Tabe $1^{1}$.

\footnotetext{
${ }^{1}$ For more studies on the methods of MS estimation, see chapters 6 and 8 of Krolzig (1997).
} 
Table 1

Different Moods of MS-VAR Models

\begin{tabular}{llllll}
\hline & & MSM & \multicolumn{3}{c}{ MSI specification } \\
\cline { 4 - 6 } & & $\mu_{\text {varying }}$ & $\mu_{\text {invariant }}$ & $v_{\text {varying }}$ & $\begin{array}{c}\nu \\
\text { invariant }\end{array}$ \\
\hline$A_{j}$ & $\sum$ & MSM-VAR & linear & MSI-VAR & linear VAR \\
invariant & invariant & & MVAR & & \\
& $\sum$ & MSMH-VAR & MSH- & MSIH- & MSH- \\
& varying & & MVAR & VAR & VAR \\
$A_{j}$ & $\sum$ & MSMA-VAR & MSA- & MSIA- & MSA- \\
varying & invariant & & MVAR & VAR & VAR \\
& $\sum$ & MSMAH-VAR & MSAH- & MSIAH- & MSAH- \\
& varying & & MVAR & VAR & VAR \\
\hline
\end{tabular}

M: Markov-switching mean

I: Markov-switching intercepts term

A: Markov-switching autoregressive parameters

$\mathrm{H}$ : Markov-switching heteroskedastic

Source: Krolzig (1998:6)

In order to investigate the causal relationship between money growth and inflation, the Granger MS causality test is used to allow the causal relationship to be variable and dependent on the regime. Based on the MS-VAR model, we will have:

$$
\left[\begin{array}{c}
B M G_{t} \\
I N F_{t}
\end{array}\right]=\left[\begin{array}{l}
\mu_{1 . s t} \\
\mu_{2 . s t}
\end{array}\right]+\sum_{k=1}^{q}\left[\begin{array}{ll}
\phi_{11 . s t}^{(k)} & \phi_{12 . s t}^{(k)} \\
\phi_{21 . s t}^{(k)} & \phi_{22 . s t}^{(k)}
\end{array}\right]\left[\begin{array}{c}
B M G_{t-k} \\
I N F_{t-k}
\end{array}\right]+\left[\begin{array}{l}
e_{t} \\
\varepsilon_{t}
\end{array}\right]
$$

Where, BMG is broad money growth, and INF is inflation. It can be said that BMG (INF) is the Granger cause of INF (BMG) if the null hypothesis $H_{0}: \phi_{12}^{(k)}=0\left(H_{0}: \phi_{21}^{(k)}=0\right)$ can be rejected (Bildirici, 2012: 6).

\section{Data and Empirical Results}

This study investigates the nonlinear causality relationship between money growth and inflation in Turkey during 1961-2019 ${ }^{1}$. As with most empirical studies in this area, we use the concept of broad money to measure the money supply. It is the most comprehensive definition for monetary aggregates and is defined as the sum of currency outside banks; demand deposits other than

\footnotetext{
${ }^{1}$ The maximum period of available data at the study time.
} 
those of the central government; the time, savings, and foreign currency deposits of resident sectors other than the central government; bank and traveler's checks; and other securities such as certificates of deposit and commercial paper (World Bank, 2020) ${ }^{1}$. Also, inflation is measured based on the consumer price index. All data are obtained from World Development Indicators ${ }^{r}$.

Figure 1 shows the plot of data sets. Inflation and broad money growth have been accelerating in Turkey since 1977, which was mainly rooted in the policy of accelerating economic growth through expansionary monetary policy. Since the 2 nd half of the 1990s, the implementation of the economic stabilization program has largely succeeded in controlling inflation and broad money growth in Turkey, so that these variables have seen lower rates and more stable trends since 2003.

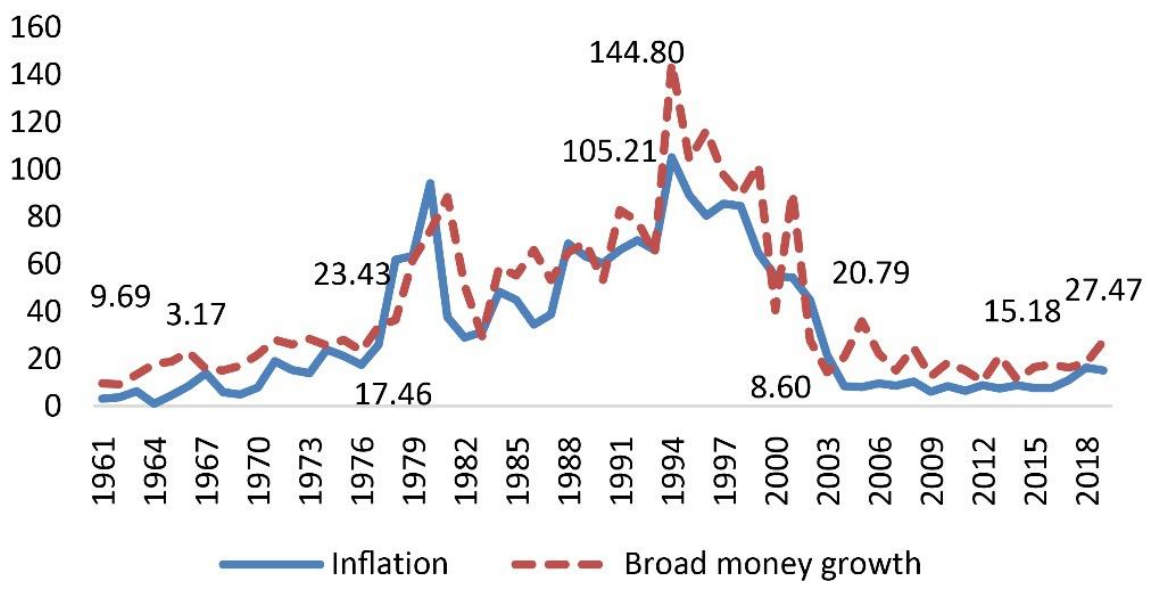

Figure 1. Broad Money Growth and Inflation in Turkey.

Source: WDI (2020)

After a brief review of the data, we have to investigate the stationarity of variables. Granger and Newbold (1973) emphasized time series stationary before regression estimation. For threshold models like MS-VAR, Franses and

\footnotetext{
${ }^{1}$ Monetary aggregates definitions are very diversified across countries. This definition is a general one and almost equals M2 (Eltejaei, 2016).

${ }^{2}$ WDI, Last Updated: 05/19/2020
} 
Van Dijk (2000) noted that there is little evidence that these patterns could create stationary time series (Zapata and Gauthier, 2003:4). We use ElliottRothenberg-Stock (ERS)' and Lumsdaine and Papell (L.P. $)^{r}$ unit root tests to examine the stationarity of time series. The results of unit root tests in Table 2 shows that both time series, BMG and INF, are stationary $(\mathrm{I}(0))$.

\section{Table 2}

\begin{tabular}{|c|c|c|c|}
\hline \multirow{3}{*}{ Variables } & ERS Test & L.P. Test & \multirow{3}{*}{ Result } \\
\hline & $\begin{array}{l}\text { H0:Variable has a } \\
\text { unit root }\end{array}$ & $\begin{array}{l}\text { H0: Variable has a } \\
\text { unit root }\end{array}$ & \\
\hline & \multicolumn{2}{|c|}{ The Value of Test Statistic } & \\
\hline $\mathrm{BMG}$ & 6.052 & $\begin{array}{l}-6.8028 \\
(1993 \& 2001)\end{array}$ & Stationary \\
\hline INF & 7.637 & $\begin{array}{l}-7.2871 \\
(1993 \& 2002)\end{array}$ & Stationary \\
\hline
\end{tabular}

* The numbers in parentheses indicate the year of structural break.

Note: Critical values for ERS test are: 1.884, 2.995 and 3.957 at the $1 \%, 5 \%$ and $10 \%$ significance levels, respectively. Critical values for LP test are: $-7.1900,-6.7500$ and -6.4800 at the $1 \%, 5 \%$ and $10 \%$ significance levels, respectively.

Source: Research Findings

To reduce residual correlation, we determine the optimal lag order of the VAR model. Literature provides various choices such as Akaike (AIC), Hannah-Quinn (H.Q.), and Schwarz (S.C.) information criteria, the

\footnotetext{
${ }^{1}$ A common criticism is that the ADF test exhibits disappointing power properties, as shown, for example, in the Monte Carlo simulations performed by DeJong et al. (1992). Elliott, Rothenberg, and Stock (1996) propose a modified version of the ADF unit-root test -called the ERS test- that has substantially improved power in the presence of an unknown intercept or trend. Elliott, Rothenberg, and Stock further show that while the statistic calculated from the GLS-demeaned data has an identical limiting representation to that of the conventional DickeyFullert statistic when there is no intercept, the limiting representation differs in the linear trend case (Otero \& Baum, 2017:986).

${ }^{2}$ Since the influential paper of Perron (1989), researchers have noted the importance of allowing for a structural break when testing for a unit root. Perron showed that the ability to reject a unit root decreases when the stationary alternative is true and a structural break is ignored. Given a loss of power when ignoring one structural break in standard unit root tests, it is logical to expect a similar loss of power when ignoring two, or more, breaks in the one-break tests. Recent research indicates that many economic time series might contain more than one structural break. Therefore, it may be necessary to allow for more than one break when testing for a unit root (Lee \& Strazicich:1). Therefore, in this paper we used Lumsdaine and Papell (1997, hereafter LP) that make a contribution in this direction by extending the Zivot and Andrews test to two structural breaks.
} 
sequentially modified likelihood ratio (L.R.), and Final prediction error (FPE) tests. We use the L.R., FPE, AIC, SC, and H.Q. tests and obtain 1 as the optimal lag order, based on all test statistics. The results are shown in Table 3.

Table 3

Results of Lag Order Selection Criteria

\begin{tabular}{llllll}
\hline Lag & LR & FPE & AIC & SC & HQ \\
\hline 0 & NA & 177225.6 & 17.76 & 17.83 & 17.79 \\
1 & $85.61^{*}$ & $38367.30^{*}$ & $16.23^{*}$ & $16.45^{*}$ & $16.31^{*}$ \\
2 & 2.90 & 41970.27 & 16.32 & 16.69 & 16.46 \\
3 & 2.75 & 45995.52 & 16.41 & 16.92 & 16.61 \\
4 & 5.03 & 47857.38 & 16.44 & 17.11 & 16.70 \\
5 & 3.52 & 51405.65 & 16.51 & 17.32 & 16.82 \\
\hline
\end{tabular}

Note: * indicates lag order selected by the criterion

L.R.: sequential modified L.R. test statistic (each test at 5\% level)

FPE: Final prediction error

AIC: Akaike information criterion

SC: Schwarz information criterion

H.Q.: Hannan-Quinn information criterion

Source: Research Findings

The next step is to determine the optimal number of regimes in the M.S. model. Due to the nuisance parameter in the null hypothesis ${ }^{1}$, the L.R. test will not have a standard distribution, which makes it inappropriate to use for determining the optimal number of regimes (Krolzig, 1997: 144). So, in most experimental studies, the number of regimens is determined based on the researcher's knowledge of the variables. Accordingly, due to the shortness of the period under study (1961-2019), different models of MS-VAR were estimated considering the 2 and 3 regimes structure, and were compared based on S.C. and AIC and finally, MSIAH(2)-VAR(1) model was selected as the optimal model ${ }^{2}$. In this model, all parameters, including the coefficients of the variables with different lags, the variance, and the intercept, depends on the regime.

The estimation results of MSIAH(2)-VAR(1) model, along with the diagnostic tests, are presented in Table 4. Based on Davies and Ang and Bekaert's probability value, the null hypothesis of the L.R. test that indicates

\footnotetext{
${ }^{1}$ For example, when we test the null hypothesis of the existence of two regimes against three regimes, the probability of transfer to regime 3 and the coefficients related to regime 3 are not available, which in the econometric literature these parameters are called disturbing parameters. ${ }^{2}$ We use the MS-VAR class of codes for OX by Krolzig (1998) to estimate the models.
} 
the linearity in the relationship between BMG and INF is rejected. Also, based on the results, the probabilities of regime persistence for the 0 and 1 regimes are 0.96 and 0.97 , respectively. It shows that if the system enters any of the 0 and 1 regimes, the transition probabilities are low, about 0.0444 and 0.0324, respectively. In addition, based on the probability value of chi-square statistics, the hypothesis of residual normality and the absence of autocorrelation error is not rejected. Also, based on the F statistic's probability value, the ARCH-LM test's null hypothesis that indicates no autoregressive conditional heteroscedasticity $(\mathrm{ARCH})$ is not rejected. Therefore, the estimated nonlinear pattern is acceptable according to the diagnostic tests.

Table 4

Maximum Likelihood Estimates of MSIAH (2)-VAR (1)

\begin{tabular}{|c|c|c|c|}
\hline \multirow[t]{2}{*}{ Variables } & Equation for BMG & \multicolumn{2}{|c|}{ Equation for INF } \\
\hline & $\begin{array}{ll}\text { Regime } 0 & \text { Regime } 1\end{array}$ & Regime 0 & Regime 1 \\
\hline Constant & $\begin{array}{c}23.22 \\
(0.037)\end{array}$ & $\begin{array}{l}27.63 \\
(008)\end{array}$ & $\begin{array}{c}1.26 \\
(0.296)\end{array}$ \\
\hline BMG_1 & $\begin{array}{c}0.17 \\
(0.150)\end{array}$ & $\begin{array}{c}-0.03 \\
(0.847)\end{array}$ & $\begin{array}{c}0.30 \\
(0.000)\end{array}$ \\
\hline INF_1 & $\begin{array}{cc}1.04 & 0.003 \\
(0.000) & (0.981)\end{array}$ & $\begin{array}{c}0.60 \\
(0.013)\end{array}$ & $\begin{array}{c}0.32 \\
(0.001)\end{array}$ \\
\hline \multicolumn{4}{|c|}{$\begin{array}{l}\text { Estimation sample: } 1962-2019 \text {, No. of observations: } 58 \text {, log-likelihood: }-411.402 \text {, AIC } \\
\text { 14.876, SC: } 15.5866\end{array}$} \\
\hline $\begin{array}{l}\text { Diagnostic statistics of } \\
\text { MS-VAR \& Linear } \\
\text { Models }\end{array}$ & $\begin{array}{l}\text { Prob. Ang and Bekaert LR T } \\
\text { Prob. Davies Test (0.005) }\end{array}$ & D001) & \\
\hline Transition probabilities & $\begin{array}{l}p_{-}\{\mathrm{i} \mid \mathrm{j}\}=\mathrm{P}(\text { Regime } \mathrm{i} \text { at } \mathrm{t}+1 \\
\mathrm{p}_{-}\{0 \mid 0\}=0.9556 \quad \& \quad \mathrm{p}_{-} \\
\mathrm{p}_{-}\{1 \mid 0\}=0.0444 \quad \& \quad \mathrm{p}_{-}\{1\end{array}$ & $\begin{array}{l}\text { ne } j \text { at } t \text { ) } \\
0.0324 \\
9676 \\
\end{array}$ & \\
\hline $\begin{array}{l}\text { Descriptive statistics } \\
\text { for scaled residuals }\end{array}$ & $\begin{array}{l}\text { Vector Normality test: } \mathrm{Chi}^{\wedge} \text { } \\
\text { Vector ARCH 1-1 test: F (4, } \\
\text { Vector Portmanteau ( } 7) \text { : Chi }\end{array}$ & $\begin{array}{l}5.3062[0 . \\
0.10677[0 \\
=24.797\end{array}$ & \\
\hline
\end{tabular}

Note: The numbers in parentheses indicate the probability $(\mathrm{P})$ value

Source: Research findings

In the next step, based on MSIAH(2)-VAR(1) model and Granger causality approach, the causal relationship between INF and BMG in 0 and 1 regimes are investigated. The results are reported in Table 5. 
Table 5

MS Granger Causality Test

\begin{tabular}{|c|c|c|c|}
\hline Regime & $\begin{array}{l}\text { Causality from } \\
\text { Growth to Inflation }\end{array}$ & Money & $\begin{array}{l}\text { Causality from Inflation to } \\
\text { Money Growth }\end{array}$ \\
\hline Regime 0 & $\begin{array}{l}0.0377 \\
(0.8460)\end{array}$ & & $\begin{array}{l}16.64 \\
(0.0000)\end{array}$ \\
\hline Regime 1 & $\begin{array}{l}17.3796 \\
(0.0000)\end{array}$ & & $\begin{array}{l}0.0006 \\
(0.9806)\end{array}$ \\
\hline
\end{tabular}

Note: The numbers in parentheses indicate the $\mathrm{p}$-value of $\mathrm{Chi}^{\wedge}{ }^{\wedge} 2$ statistics

Source: Research findings

Before interpreting the causality test results in different regimes, based on the model estimation results, we have to identify different regimes years and the status of BMG and INF in each regime. According to Figure 2, which shows the MSIAH(2)-VAR(1) model, regime 0 includes 1977-2001, and regime 1 includes 1976-1962 and 2019-2002. It should be noted that the average BMG and INF in regime 0 are $72.27 \%$ and $60.98 \%$ and in regime 1 are $19.66 \%$ and $11.42 \%$, respectively.
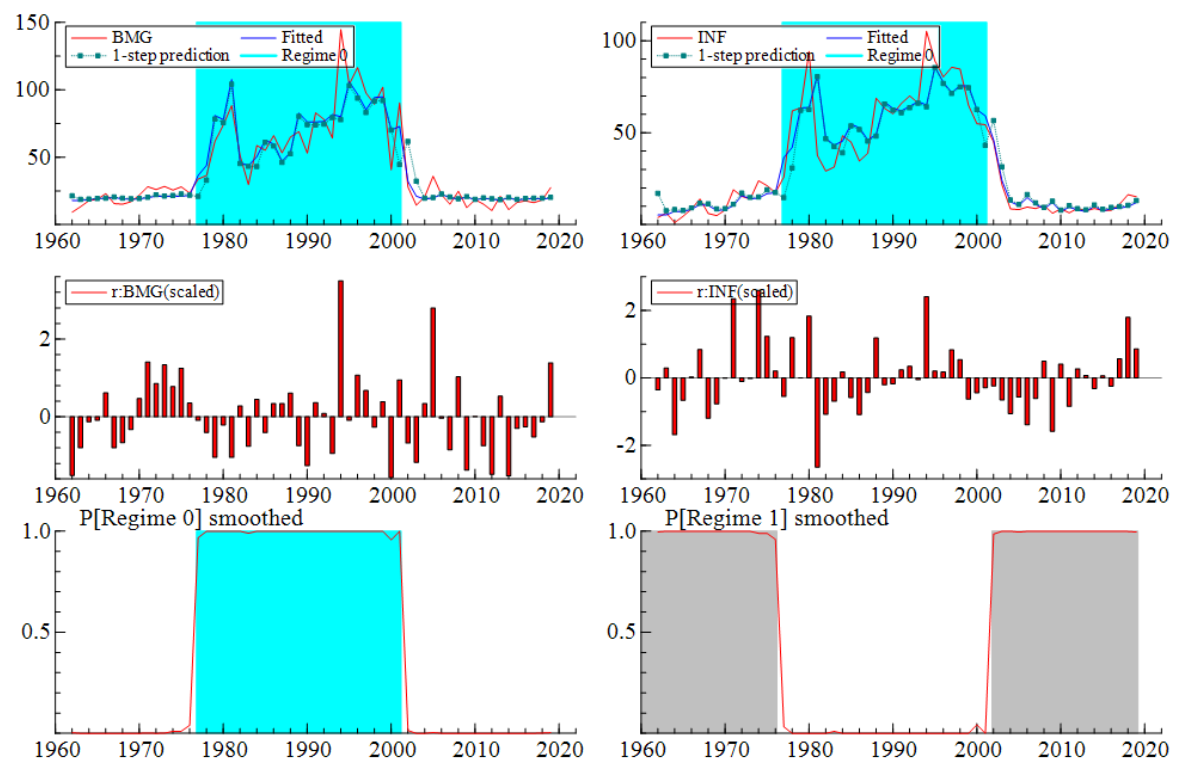

Figure 2. Actual and Fitted Values, Regime Probabilities, and Fitted Regimes of MSIAH(2)-VAR(1) Model.

Source: Research findings 
Based on the results of the nonlinear causality test between broad money growth and inflation in Turkey (listed in tables 3 and 4) and the status of inflation and broad money growth in regimes 0 and 1 , it can be inferred that the causal relationship between the BMG and INF was not constant and was varying depending on the situations of these variables in the Turkish economy. The findings show that there was a one-way causal relationship between inflation and broad money growth at high rates of inflation and broad money growth (Regime 0: 1977-2001). In this regime, inflation with a coefficient of 0.6 had a positive and significant effect on broad money growth. So in high inflationary periods, commensurating with Post-Keynesians' ideas, money is endogenous, and controlling inflation does not depend on money growth. Whereas, over the period when the Turkish economy experienced milder inflation rates and broad money growth (Regime 1: 1976-1962 and 20192002), there was a one-way causal relationship from broad money growth to inflation. In this regime, broad money growth with a coefficient of $0.32 \mathrm{had}$ a positive and significant effect on inflation.

Although there has been no similar study for the Turkish economy, findings of this study confirm Hamilton (1994) viewpoint, and like Amisano and Colavecchio (2013), Amisano and Fagan (2013), Cooray and Khraief (2019), and Eltejaei (2020) showed that the causal relationship between money growth and inflation despite theoretical literature is not linear necessarily.

\section{Conclusion}

There is no theoretical or empirical consensus among economists in explaining the causal relationship between money growth and inflation. It seems that the economic situation is quite important to determine the direction of this causal relationship. We empirically studied the causal relationship between broad money growth and inflation in Turkey using the MS-VAR approach for the period of 1961-2019. In this regard, the stationarity of variables was evaluated using the ERS and L.P. tests. Then, due to the shortness of the studied period, MSIA-VAR and MSIAH-VAR patterns were estimated considering 2 and 3 regimes structure and were compared by S.C. and AIC criteria. So, a MSIAH(2)-VAR(1) model was selected as the optimal model. The findings of model estimation showed that the causal relationship between BMG and INF was not constant but varied depending on the situation of the variable. Findings also showed that over the period 1977-2001, when the Turkish economy was highly inflationary, there was a one-way causal relationship from inflation to broad money growth, whereas, over the period 
1976-1962 and 2019-2002, when the Turkish economy experienced milder inflation rates, there was a one-way causal relationship from broad money growth to inflation.

In terms of policymaking, the findings of this study can be considered in three aspects: First, in accordance with Hamilton (1994), the causality relationship between money growth and inflation is not necessarily constant, but, depending on the circumstances and time requirements, this relationship can be nonlinear. Secondly, controlling inflation is not simply dependent on money growth in high inflationary periods. In this case, commensurating with Post-Keynesians' ideas, money is endogenous, so the other determinants of inflation have to be controlled to prevent the reproduction of money growth or the reverse causality. According to Mehrara and Behzadi Soufiani (2015), these determinants can be exchange rate, budget deficit, and inflationary expectations. Thirdly, in the ranges of moderate inflation, money growth control policies will lead to meaningful control of inflation.

Finally, as said before, based on previous empirical studies, there have been different results of a causal relationship between money and inflation depending on the sample. However, most of them have supposed a linear relationship. We must find more evidence about the nonlinear relationship, so we suggest more studies using the nonlinear methods in different countries and periods.

\section{References}

Aghevli, B., \& M. Khan (1978). Government Deficits and the Inflationary Process in Developing Countries. International Monetary Fund Staff Papers. 383-416. Retrieved from

https://www.sciencedirect.com/science/article/pii/B9780080240411500302

Amisano, G., \& Colavecchio, R. (2013). Money Growth and Inflation: Evidence from a Markov Switching Bayesian VAR. Hamburg University, Department of Wirtschaft und Politik Macroeconomics and Finance Series Discussion, Paper 4. Retrieved from https://ideas.repec.org/p/hep/macppr/201304.html

Amisano, G., \& Fagan, G. (2013). Money Growth and Inflation: A Regime Switching Approach. Journal of International Money and Finance, 33, 118-145.

Atrkar Roshan, S. A. R. (2014). Inflation and Money Supply Growth in Iran: Empirical Evidences from Cointegration and Causality. Iranian Economic Review, 18(1), 131-152.

https://ier.ut.ac.ir/article_53293_9e45930e54b05973c2a5897672dc8d9f.pdf

Benderly, J., \& B. Zwick (1985). Money, Unemployment, and Inflation. Review of Economics and Statistics, 67, 139-143. 
Bildirici, M. (2012). Economic Growth and Electricity Consumption in Africa and Asia: MS-VAR and MS-Granger Causality Analysis. MPRA_paper_41796. Retrieved from https://mpra.ub.uni-muenchen.de/41796/

Cooray, A., \& Khraief, N. (2019). Money Growth and Inflation: New Evidence from a Nonlinear and Asymmetric Analysis. The Manchester School, 87(4), 543-577.

DeJong, D. N., Nankervis, J. C., Savin, N. E., \& Whiteman, C. H. (1992). The power problems of unit root test in time series with autoregressive errors. Journal of Econometrics, 53(1-3), 323-343.

Denbel, F. S., Ayen, Y. W., \& Regasa, T. A. (2016). The Relationship between Inflation, Money Supply and Economic Growth in Ethiopia: Co-integration and Causality Analysis. International Journal of Scientific and Research Publications, 6(1), 556-565.

Deschamps, Ph. J. (2008). Comparing Smooth Transition and Markov Switching Autoregressive Models of Us Unemployment. Journal of Applied Econometrics, 23(4), 435-462.

Elliott, G., Rothenberg, T. J. \& J. H. Stock. (1996). Efficient Tests for an Autoregressive Unit Root. Econometrica, 64, 813-836.

Eltejaei, E. (2020). Investigating the Causality between Money and Inflation in Iran: A MS-VAR Approach. New Economy and Trade, 15(3), 3-26.

Eltejaei, E. (2016). A Historical Analysis of Monetary Aggregates Definition Related to Financial Innovations. Quarterly Journal of Fiscal and Economic Policies, 3(12), 29-56.

Fallahi, F. (2011). Causal Relationship between Energy Consumption (E.C.) and GDP: A Markov-Switching (M.S.) Causality. Energy. 36(7), 4165-4170.

Fatma Turan, K. (2014). Causality Network between Budget Deficit, Money Supply, and Inflation: An Application to Turkey. International Journal of Business and Social Science. 5(10), 225-235.

Fisher, I. (1911). The Purchasing Power of Money. New York: Macmillan. Chs 1-4, 8.

Franses, P. H., \& Van Dijk, D. (2000). Nonlinear Time Series Models in Empirical Finance. Cambridge: Cambridge University Press.

Friedman, M. (1958). The Supply of Money and Changes in Prices and Output. Reprinted In Friedman, M., The Optimum Quantity of Money and Other Essays. Chicago: Aldine. 1969.

Friedman, M., \& Schwartz, A. (1963). The Monetary History of the United States, 1867-1960. Princeton. NJ: Princeton University Press.

Goldfeld, S., \& Quandt, R. (1973). The Estimation of Structural Shifts by Switching Regressions. In Annals of Economic and Social Measurement, Vol. 2, Number 4 (pp. 475-485). NBER.

Göçmen, T. (2016). Causal Relationship between Money and Inflation during a High Inflation Period: The Case of Turkey. Journal of International Business and Economics, 4(2), 1-11. 
Granger, C. W. J., \& Newbold, P. (1973). Some Comments on the Evaluation of Economic Forecasts. Applied Economics, 5(1), 35-47.

Hamilton, J. D. (1989). A New Approach to the Economic Analysis of Nonstationary Time Series and the Business Cycle. Econometrica, 57(2), 357-384.

Hamilton, J. D. (1994). Time Series Analysis. Princeton: Princeton University Press. Handa, J. (2009). Monetary Economics. 2nd Edition. New York: Routledge.

Holt, R. P. F., \& Pressman, S. (2001). A New Guide to Post-Keynesian Economics. London and New York: Routledge.

Hume, D. (1752a). Of Interest, Reprinted, In The Philosophical Works of David Hume. 4 volumes. Boston: Little Brown. 1954.

Hume, D. (1752b). Of Money, Reprinted in The Philosophical Works of David Hume. 4 Volumes. Boston: Little Brown. 1954.

Indalmanie, S. P. (2011). The Relationship between Money Supply and the Rate of Inflation: A Causality Approach to the Study of the Jamaican Economy, 19612006. Retrieved from

https://www.researchgate.net/publication/315434291_The_Relationship_between_

Money_Supply_and_the_Rate_of_Inflation_A_Causality_Approach_to_the_Stu dy_of_the_Jamaican_Economy_1961-2006

Jones, J. D., \& Khilji, N. M. (1988). Money Growth, Inflation, and Causality (Empirical Evidence for Pakistan, 1973-1985). The Pakistan Development Review, 27(1), 45-58.

Jones, J. D., \& Uri, N. D. (1987). Money, Inflation, and Causality: Another Look at the Evidence for the U.S. 1953-84. Applied Economics. 19(5), 619-634.

Kesavarajah, M., \& Amirthalingam, K. (2012). The Nexus between Money Supply and Inflation in Sri Lanka. In Jaffna University International Research Conference (Vol. 232).

Kiganda, E. O. (2014). Relationship between Inflation and Money Supply in Kenya. Journal of Social Economics, 2(2), 63-83.

Kim, C. J., \& Nelson, C. R. (1999). State-space Models with Regime Switching: Classical and Gibbs-sampling Approaches with Applications. MIT Press Books, 1.

Korkmaz, S. (2018). The Relationship between Money Supply, Inflation and Economic Growth in Mediterranean Countries. Department of Economics, Faculty of Economics and Administrative Sciences, Bandirma Onyedi Eylul University.

Krolzig, H. M. (1998). Econometric Modelling of Markov-Switching Vector Autoregressions Using MSVAR for Ox. Oxford: Institute of Economics and Statistics and Nuffield College.

Krolzig, H. M. (1997). Markov Switching Vector Autoregressions: Modelling, Statistical Inference and Application to Business Cycle Analysis. Berlin: Springer.

Lee, J., \& Strazicich, M. (1999). Minimum L.M. unit root test with two structural breaks. Department of Economics, University of Central Florida Working Paper Series. 
Lumsdaine, R. L., \& Papell, D. (1997). Multiple Trend Breaks and the Unit-Root Hypothesis. The Review of Economics and Statistics, 79 (2), 212-218.

Mehrara, M., \& Behzadi Soufiani, M. (2015). The Threshold Impact of Fiscal and Monetary Policies on Inflation: Threshold Model Approach. Journal of Money and Economy. 10 (4), 1-27.

Otero, J., \& Baum, C. F. (2017). Response Surface Models for the Elliott, Rothenberg, and Stock Unit-Root Test. The Stata Journal, 17(4), 985-1002.

Perron, P. (1989). The Great Crash, the Oil Price Shock, and the Unit Root Hypothesis. Econometrica: journal of the Econometric Society, 57, 1361-1401.

Pigou, A. C. (1917). The Value of Money. Quarterly Journal of Economics, 32, 3865.

Quandt, R. E. (1972). A New Approach to Estimating Switching Regressions. Journal of the American Statistical Association, 67(338), 306-310.

Sasongko, G., \& Huruta, A. D. (2018). Monetary Policy and the Causality between Inflation and Money Supply in Indonesia. Business: Theory and Practice, 19, 8087.

Sultana, N., Koli, R., \& Firoj, M. (2019). Causal Relationship of Money Supply and Inflation: A Study of Bangladesh. Asian Economic and Financial Review, 9(1), 42-51.

Turnovsky, S., \& Wohar, M. (1984). Monetarism and the Aggregate Economy: Some Longer Run Evidence. Review of Economics and Statistics, 66, 619-629.

Tymoigne, E., \& Wray, L.R. (2013). Modern Money Theory 101: A Reply to Critics, Levy Economics Institute of Bard College. Working Paper No. 778. Retrieved from https://www.levyinstitute.org/pubs/wp_778.pdf

Wicksell, K. (1907). The Influence of the Rate of Interest on Prices. Economic Journal, 17, 213-220.

World Bank (2020). World Development Indicators.

Zapata, H. O., \& Gauthier, W. M. (2003). Threshold Models in Theory and Practice. 2003 Annual Meeting, February 1-5, 2003, Mobile, Alabama 35147, Southern Agricultural Economics Association.

Zivot, E. and. Andrews, D. W. K (1992). Further Evidence on the Great Crash, the Oil-Price Shock and the Unit Root Hypothesis. Journal of Business and Economic Statistics, 10 (3), 251-270.

Zulkhibri, M. (2007). Causality Link between Money, Output and Prices in Malaysia: An Empirical Re-Examination. Applied Econometrics and International Development, 7(1), 1-19. 